\title{
PARADOX OF WHITE COLLAR CRIME AND FRAUD IN BANKING: CRITICAL ANALYSIS OF AGENCY THEORY AND GONE THEORY
}

\author{
Nanang Shonhadji ${ }^{*}$ \\ STIE Perbanas Surabaya \\ 34-36, Nginden Semolo St., Surabaya, \\ Indonesia 60118 \\ nanang@perbanas.ac.id
}

\begin{abstract}
This study aims to criticize the causal relationship between agency theory and GONE theory with Habermas's radical humanist paradigm. Qualitative research methods and in-depth interviews with informants were used in this study. The study results are that agents can be free from pragmatic agency theory through three forms of exemption. The first liberation proposed is to reduce one's greediness. The second release was carried out through an ethical and moral customer due diligence program. The liberation of the third form aims to reduce the rationality of economic relations that prioritize individuals' needs.
\end{abstract}

Keywords: Bank accounting; Fraud; White corral crime; Consciousness; Enlightenment

\begin{abstract}
ABSTRAK
Penelitian ini bertujuan untuk mengkritisi hubungan kausalitas antara agency theory dan GONE theory dengan paradigma radical humanis Habermas. Metode penelitiaan kualitatif dan wawancara mendalam dengan informan digunakan dalam penelitian ini. Hasil penelitian menginformasikan bahwa agent dapat terbebaskan dari penerapan agency theory yang bersifat pragmatis melalui tiga bentuk pembebasan. Pembebasan pertama yang diusulkan adalah mereduksi sifat serakah pada diri seseorang. Pembebasan bentuk kedua dilakukan melalui program customer due diligence yang beretika dan bermoral. Pembebasan bentuk ketiga bertujuan untuk mereduksi adanya rasionalitas hubungan ekonomi yang cenderung mementingkan kebutuhan individu.
\end{abstract}

Kata Kunci: $\quad$ Akuntansi bank; Kecurangan; Kejahatan kerah putih; Kesadaran; Pencerahan

JEL Classification: M410

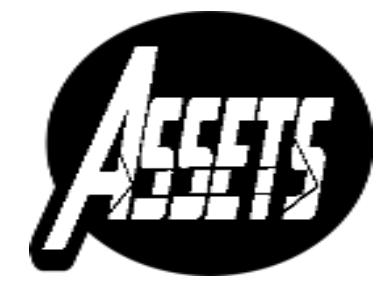

ASSETS

Jurnal Akuntansi dan Pendidikan

Vol. 9 No. 2

Page 142-155

Madiun, October 2020 p-ISSN: 2302-6251 e-ISSN: 2477-4995

Article History Submitted: May 4, 2020 Accepted: October 22, 2020 


\section{INTRODUCTION}

The development of research in banking accounting has reached its focus, especially on the scope of fraud involving banks and their customers. Today's development of banking technology has made it easier to move their customers across local regions within the national scope. Besides that, information technology in the banking sector also makes it easy to transfer the banks' funds across countries (Hayashi, 2019). This is due to the globalization of the banking system through electronic payment systems. In this case, the proceeds of crime are generally in a large amount that will flow or move beyond state jurisdiction limits by utilizing the bank's confidential factor, which is highly valued by banks.

This crime is often referred to as white-collar crime. White-collar crime is an act of cheating committed by someone who has a high enough position and authority in the government or private sectors (Shonhadji \& Maulidi, 2020). Baer (2018), Berghoff and Spiekermann (2018) said that white-collar crime is a crime committed by someone who is very respectable and has a high social status in his work. This crime can occur within companies, professionals, commerce, and political life. In understanding whitecollar crime in banking, knowledge is needed. This knowledge is related to the typology of the perpetrators of the crime. The first typology is seen from the bank employee's social status, whether it comes from being honorable or not (Mira, 2014; Sun, Wang, Jiang, \& Wang, 2018; Taylor, 2018). Honorary status, in this case, is a high position held by the bank employee. Various forms of white-collar crime that generally occur include fraud, corruption, bribery, fraud, and money laundering (Pluchart, 2019; Weirich \& Churyk, 2018).

Berghoff and Spiekermann (2018); Baer (2018), and Reurink (2018) said that many white-collar criminals are motivated by their intention to gain personal or group benefits by utilizing the existing procedures and policy gaps they think it as legitimate activities and not to violate the provisions of the law. This phenomenon has its relation to the banking service industry, which is a massive inseparable phenomenon (Ketz, 2019). This is due to the truth that money laundering cases are carried out by utilizing banking service products, both funding products such as savings, current accounts, and deposits but also bank services in the form of transfers (Mira, 2014; Rechtman, 2020). It is recognized that banking's core business is collecting funds from customers in the form of deposits and then channeling loans to customers in credit or loans (J.R.Saroinsang, 2014; Yoon \& Jun, 2019).

Agency theory is the basis for business people in causal relationships between principals and agents. The actual principal is a person or group of people who have money or assets in the form of investment in a business organization such as shares that is entrusted to a person or group of people of the company to carry out management in business activities to achieve profits (Azam, 2018; Lan \& Heracleos, 2010). An agent refers to a person or group of people given the authority and trust to manage the business in an agency theory. The thing that needs to be observed is that contextual agency theory is not merely a relationship of authority cooperation between the principal and the agent, but rather the goal of getting the maximum profit (Shonhadji \& Maulidi, 2020). This can be indicated by the principal who is willing to spend a significant amount of money just to carry out control and supervision (Hayashi, 2019; Ruan, Xiang, \& Ma, 2018).

In this space, money laundering crimes get loopholes, and there is a need for savings from large customers as a source of lending to the community that will later be used to meet the principal's target of maximizing profits; on the other hand, money

This work is licensed under a Creative Commons Attribution-ShareAlike 4.0 International License. 
laundering criminals get a place to satisfy their greedy nature over the proceeds of crime. The Mega Bank case involved in PT Elnusa's money laundering crime case in 2011-2012, then the most recent in February 2019 BRI tellers involved money laundering case (Hariyadi, 2019). Internationally the largest bank in Germany, Deutsche Banks in Frankfurt, was investigated by law enforcers connected with money laundering cases involving employees for criminal activities (Hikam, 2018).

Research conducted by Mathilda (2013) and Baer (2018) informs that money laundering impacts economic activity, especially concerning financial institutions. Research on white-collar crime in the banking sector was also carried out by Garnasih (2013); Taylor (2018), and Hayashi (2019), who informed that white-collar crime involved many banking sectors. Causality of the contextual relationship between agency theory and GONE theory becomes a paradox that is motivated by materialistic transactional needs. This study aims to criticize the paradoxical causal relationship with the critical paradigm of Habermas.

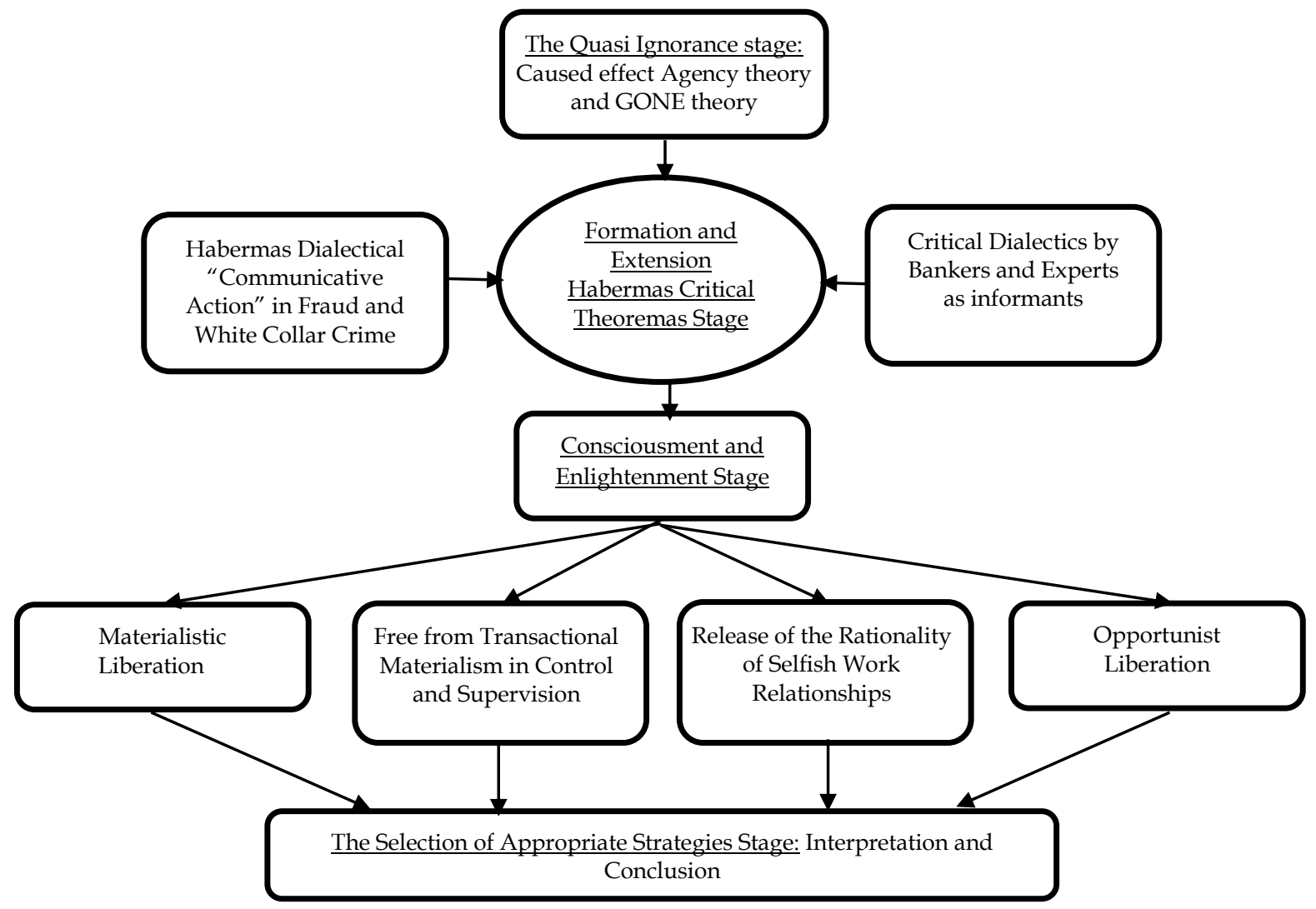

Figure 1. Research Framework

Source: extended by researcher (2020)

Conceptually, the theoretical research framework is systematically combined with the research method proposed by Sawarjuwono (2005), Iwan (2014), and Supraja (2018). It is done by carrying out several modifications that have been adjusted to the research object. The following is an overview of the conceptual framework as described as three phases: first, the quasi ignorance phase is the preparation stage before research is carried out. It is carried out through a literature review and documentation study. Second, the formation and extension of the critical theoremic stage is the stage of understanding the research object through examination related to social documents, critical dialectics, and interpretation. Third, the consciousness and enlightenment stage 
is part of the process of complaints made by reflecting, and it is carried out on the concepts of ethics and morality, and spiritual merged with GONE theory. The selection of the Right Strategy Phase is a conclusion, evaluation, and verification, through a process of synthesis of understanding the meaning of the reality of fraud and whitecollar crime in banking.

\section{METHOD}

This research is a type of qualitative research using the Critical Paradigm of the particular paradigm of Radical Humanism in looking at the phenomenon of banking accounting. The Radical Humanism paradigm sees change as done through consciousness and enlightenment. The Critical Paragraph is used because it has a dual purpose, namely about how to apply the applied accounting and, at the same time, support to find the direction of improvement (Supraja, 2018).

It is using Habermas as a critical analysis method. Habermas is known for his theory, namely The Theory of Communicative Action, which is often used to analyze social interactions through the separation of two fundamental interactions, namely: (1) interaction based on social needs (lifeworld); and (2) interactions that are influenced by system mechanisms. Sawarjuwono (2005), Omika Dewi (2010), and Supraja (2018) states that social interactions included in the concept of lifeworld are social activities carried out without any element of coercion and it occurs in an atmosphere of communicative action. Furthermore, a social interaction which is included in the concept of system mechanism is a social activity carried out due to an element of compulsion, and it does not occur in an atmosphere of communicative action because steering media influence it, namely media money (economic considerations) and media power (regulations).

By the Habermas language paradigm view, researchers see that a company cannot stand alone without social interaction with stakeholders and the community (Iwan, 2014; Supraja, 2018). Social interaction, in this research, is the relationship between employees or bank employees (agents) and capital owners (principals) who interact in business relationships with a maximum profit-oriented orientation while at the same time social interaction between money laundering actors and bank employees with disguised orientation of transactions.

To answer the research question based on its philosophical thinking, the researcher categorized the social interaction model into three points: first, noncompliance if social interaction is based more on economic considerations (media money). Second, in-compliance if social interaction is based on economic considerations (media money) and compliance with regulations (media power) and beyond compliance, if social interaction is based on a consciousness that exceeds economic considerations (media money) or compliance with regulations (media power).

This research was conducted in the case of white coral reef crimes at Bank X, with the type of data derived from interviews with the informants, and this was carried out entirely with the intention that no results could be generalized. Data collection was conducted by an in-depth interview method by linking the synthesis of the Agency theory and GONE theory through the Habermas language paradigm (Iwan, 2014). It can represent the language interpretation, concrete external objectives for social and historical conditions at different times and places. Through language, it can be known how injustice will be revealed and how humans overcome various problems. The selected informant was informant $(\mathrm{F})$, who as a whistleblower at white-collar crime 
case in his bank, informant $(\mathrm{G})$ is middle management in Bank $\mathrm{X}$ who responsible for managing account officer staff, and informant $(\mathrm{H})$ is an expert scholar in fraud accounting and white-collar crime issues.

The critical dialectical method proposed in this study is developing data analysis techniques carried out by Iwan (2014) and Supraja (2018). This research began with the process of collecting data in advance through interviews with the informants. After that, it was continued by the data analysis process carried out through three stages, such as (a). Data reduction (initial tracing) is a form of analysis that depends, classifies, directs, discards the unnecessary data, and organizes them by making it easier to display. From this, conclusions were drawn and obtained. (b). Data presentation is a stage of data analysis carried out by dialoguing information presented in each company's sustainability report with social documents supported by the sponsor. (c). The results of this critical dialectical process were then presented in narrative texts; then, they were interpreted by the theory of communicative action from Habermas, making it easier to complete conclusions on the accounting facts found. Conclusion as the final research was finally done. It is a process of analyzing the data taken to draw conclusions that do not include discussion for researchers to verify the conclusions that have been drawn. There is a verification process that supports research to increase confidence in the research findings.

\section{RESULT AND DISCUSSION}

The concept of agency theory is the relationship or contract between the principal and the agent. Principals employ agents to carry out tasks in the principles' interests, including delegation of authorization for decision-making from principals to agents. In companies whose capital consists of shares, the shareholders act as principals, and the CEO (Chief Executive Officer) as their agent. The shareholders employ the CEO to act by the principal's interests. C.Jensen and H.Meckling (1976) explain the existence of conflicts of interest in agency relationship. The existence of differences in position, function, situation, goals, interests, and background between the principal and the agents that conflict with one another can lead to conflict of interest or conflict of interest and influence between one another.

Principals and agents are assumed to be motivated by self-interest. Therefore, differences in interests can lead to information asymmetry. Besides, agency theory assumes that all individuals act on their behalf (Reurink, 2018). Principals are only interested in increased financial returns or investments in the company. On the contrary, the agent is assumed to receive satisfaction in financial compensation and the conditions that accompany the relationship. In the banking sector, the application of agency theory is unique because this sector is different from other industries. One of them is stringent regulations, which results in applying agency theory in banking accounting to be different from accounting for non-banking companies. With this regulation, there are other parties involved in the agency relationship, namely the regulator, in this case, the government through Bank Indonesia (BI), which acts as the principal and banks in Indonesia as its agents. BI must oversee banking activities and performance in Indonesia.

GONE theory was put forward by Bologna, Lindquist, and Wells (1993), which was also revealed in the National Corruption Eradication Strategy by the KPK 2019. Four factors drive a person to commit fraud, known as the GONE theory, as the following: first, greed is related to humans' potential greedy behavior. Lifestyle that exceeds abilities or unforeseen needs is also a factor that causes someone to do unnatural things considered to be natural. Second, it is an opportunity related to the 
state of the organization, agency, and community so that it is open for someone to commit fraud against it. The condition of the agency or organization that considers that cheating is a common thing can trigger cheating perpetrators. This is increasingly widespread, and therefore, many perpetrators of fraud assume that what is done is a reasonable action carried out by others. Third, it is need that is related to the factors needed by individuals who support their lives naturally. This sometimes needs to exceed the financial capabilities that can cause harmful things by justifying any means. Fourth, it is exposure related to the possibility of disclosure of fraud and the nature and severity of the sentence against fraud perpetrators. However, it cannot be denied that disclosure cannot guarantee someone to repeat acts of fraud or crime either by the old or even the new perpetrators (Karyono, 2013; Mintchik \& Riley, 2019; Weirich \& Churyk, 2018).

The agency theory and GONE theory researcher's motivation content has found paradoxical relation as a trigger fraud and white-collar crime are happen. This stage begins with an understanding of the informants' views on the motivations and causes of fraud and white-collar crime in banking services through an in-depth examination process of social documents. This was done by interviewing the critical informants formed into a critical dialectic condition and then interpreted by the researchers. This process was then referred to as the formation and extension of the critical theorems stage.

Critical dialectics between these three key informants debates the mode and causes of fraud and white corral crime, using Habermas's communicative action approach. In this case, the researcher is already at the stage of "the formation and extension of critical theorems. It is a stage of understanding that bank employees' motives commit fraud or white corral crime because of money, the satisfaction of personal needs, pressure from superiors, and a non-conducive work atmosphere. All these have caused employees to have deviant behavior to express their behavior due to the pressure. Dialectics is formed from the following conversation between the researcher and the informant $(\mathrm{F})$ :

"Money laundering crimes in banks are mostly caused by weak internal bank supervision, anti-money laundering (AML) programs. In banks, supervision is generally carried out through a supervisory mechanism by the board of directors and the board of commissioners and internal control procedures performed by the internal auditor work unit (IAWU). The problem is that the monitoring already exists. However, the white corral rime involving unscrupulous bank employees also keeps happening ... so in my opinion, no matter how good the bank's control system is if the employees are inclined to a fraudulent motive and their orientation is always towards money, then crime and finally fraud occurs."

Disclosure of the informant $(\mathrm{F})$, if criticized by the critical theory of communication of Habermas, informs that the bank has prepared a set of tools to conduct surveillance. However, using the monitoring tools is that if bank employee performance goals and motivations are money-oriented, the opportunity to commit fraud or white corral crime will occur either. Banks employees have this orientation cannot be separated from dogma's pragmatic influence inherent in agency theory.

The researcher found weaknesses and errors in agency theory practice in the banking services business, causing bank employees to commit fraud and white corral crime. In this examination process, the researcher found that the perpetrators of fraud and white corral crime in the banking system we are trapped in pragmatic agency theory, so the results of this study inform as follows: 
First, the ideology of agency theory tends to shape bank employees to be materialistic. A study conducted by Donaldson and Preston (1995) and Lan and Heracleos (2010) stated that this theory has already created a materialistic ideology for shareholders (principals) and ignores the agent's happiness rights (management and employees). As a result, the agent will commit fraud and involvement in white-collar crime by anticipating the existing rules and exploiting internal bank supervision's weaknesses. Besides, agency theory has misunderstood the concept of economic management that should be carried out holistically by considering economic and noneconomic aspects, namely self-recognition, achievement opportunities, the right to balance, and justice to get happiness stakeholders (Shonhadji \& Maulidi, 2020).

Furthermore, the researcher also discovered the fact that employees (agents), in reality, often work under the target pressure of the principal principals on credit marketing and funding. The reality of credit marketing in the consumption credit section is often done to ignore the principle of prudence in capturing customers. They offered consumers very aggressively without collateral with an interest of $11 \%-15 \%$ for credit and credit cards. They did it without the need to know the principle of customers' ability to repay loans to use all means to achieve these targets. This can be seen from the statements of the following informants. The results of interviews with competent research scholars in the area of fraud and white-collar crime are said as the following:

"Fraud or white-collar crimes that are victimized generally have a fictitious credit mode and offer deposits from customers, but withdrawing funds from the customer's account is unknown to the account holder's customers ... this is a structured crime that involves not just one part of the bank."

Informant $G$ also added that unscrupulous employees could do that because it could be due to pressure from the community's target amount from the community collected with a vast amount from management. Not to mention the opportunity for unscrupulous bank employees to deal directly with money lounders to make commitments that lead to individual interests and money motives.

However, the facts also confirm that banks currently have implemented good governance and risk management principles. Therefore, fraud and white corral crime still occur. This cannot be separated from the weak supervision and lack of proper functioning of the bank's risk management (Sridharan \& Hadley, 2018). This is finally linked to the professional integrity capacity of the bank employees themselves. This information was obtained from the informant $(\mathrm{H})$, who disagreed with the two informants' statements. During an interview, the informant $(\mathrm{H})$ said the information as follows:

"... should the bank carry out its supervisory function to support the government's anti-money laundering program through the supervision of directors, supervisory commissioners, good internal control, it will not happen, but we admit that it is only a device ... if a good apparatus but the person is not good, it can still create opportunities for crime and fraud ..."

This dialectic creates a communication space for Habermas's statement that the rationality of the working relationship between the principal and agent is formed based on achieving the profit target for the principal. The results of this study provide evidence that agency theory is not widely looking at the working relationship between principals and agents that are motivated by personal and group gain as the ultimate goal. This criticism is very reasonable because the rationality of the relationship 
between the principal and the agent's reality in work is not always only with the motive of looking for personal advantage. There is also a motive of desiring good work (compulsive behavior), the consciousness to do and want to do something that is considered acceptable (normatively governed behavior), and the desire to do work happily (intrinsic motivation) (Donaldson \& Preston, 1995). Reurink (2018) and Mintchik and Riley (2019) added that the motive for rationalizing the relationship between principal and agent was also based on altruistic matters which were oriented towards happiness between agents and principals proportionally.

This critical analysis is reasonable because contextually, the actualization of Agency theory in practice is widely used to distribute happiness and welfare between principals and agents disproportionate. Besides that, the percentage of happiness and welfare for principals is too excessive when compared to those allocated to happiness and employee welfare (agents) (Lan \& Heracleos, 2010). This opinion is supported and in line with research conducted by who reported that the more extensive and broader its size, the bigger the distribution of the proportion of income distribution depends on management and employees (Lai, Lei, \& Song, 2019).

Habermas's critique theory sees and reads social interactions that occur in the phenomenon of fraud and white-collar crime in banking is included in the concept of system mechanism. It also includes the principal's target profit pressure to the agent occurs because of the element of compulsion and occurs not in an atmosphere of communicative action. It is due to the steering media, namely media interest in money (economic considerations) and media power, namely pressure from the principal. When social interaction is triggered by pressure from the principal to the agent with economic interests, it will create fraud and white corral crime opportunities in the banking services business.

Table 1. Paradox Agency Theory and Gone Theory

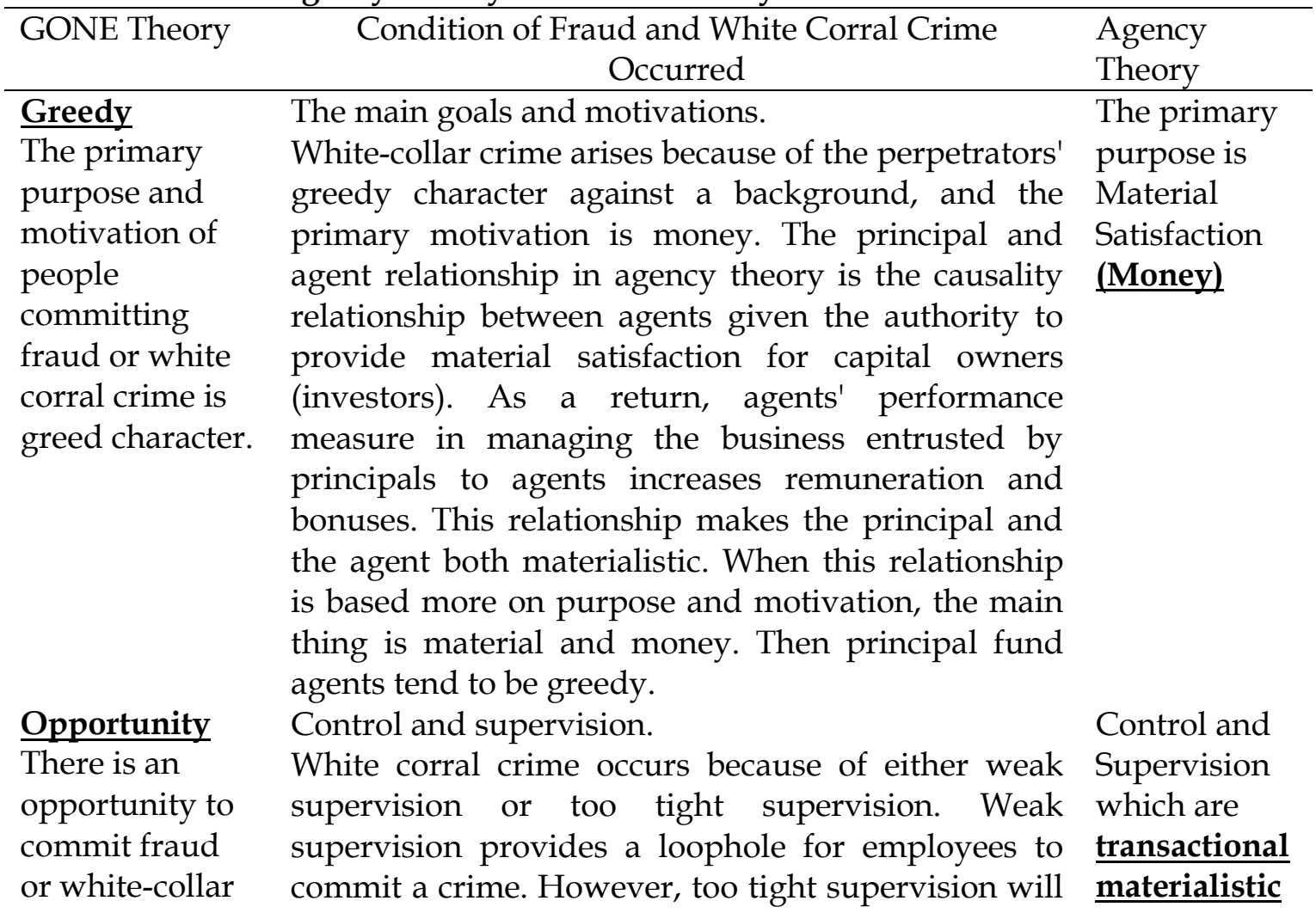




\begin{tabular}{|c|c|c|}
\hline GONE Theory & $\begin{array}{c}\text { Condition of Fraud and White Corral Crime } \\
\text { Occurred }\end{array}$ & $\begin{array}{l}\text { Agency } \\
\text { Theory }\end{array}$ \\
\hline $\begin{array}{l}\text { crime. It occurs } \\
\text { when control } \\
\text { and supervision } \\
\text { are weak. }\end{array}$ & $\begin{array}{l}\text { also cause employees to feel too restrained and feel } \\
\text { not valued (losing the meaningfulness of life). } \\
\text { Therefore, in Franklin psychology, this condition } \\
\text { triggers someone under pressure to look for } \\
\text { opportunities to commit crimes in retaliation for } \\
\text { restraint feelings. } \\
\text { Principal supervision of the agent ensures that } \\
\text { business operations run by the principles' wishes. } \\
\text { When the agent meets the target principal, the bonus } \\
\text { will be given, but there will be a reduction in } \\
\text { directors' bonuses and replacement. Supervision by } \\
\text { the principal of this partial agent tends to be } \\
\text { transactional materialistic so that it opens } \\
\text { opportunities for agents to commit fraud or white } \\
\text { corral crime. }\end{array}$ & \\
\hline Need & Employment Relations & Rationale of \\
\hline $\begin{array}{l}\text { Fraud and } \\
\text { white corral } \\
\text { crime occur } \\
\text { because of the }\end{array}$ & $\begin{array}{l}\text { Agency theory is too narrow, looking at the working } \\
\text { relationship between the principal and the agent } \\
\text { laden with motives for seeking personal and group } \\
\text { benefits as the ultimate goal. }\end{array}$ & $\begin{array}{l}\text { working } \\
\text { relationship } \\
\text { Egoism } \\
\text { (individual) }\end{array}$ \\
\hline $\begin{array}{l}\text { rationale of } \\
\text { economic } \\
\text { relations that } \\
\text { tends to divert } \\
\text { individual } \\
\text { needs by all } \\
\text { means. }\end{array}$ & $\begin{array}{l}\text { The principal-agent fund relationship is only } \\
\text { concerned with individual interests, the majority of } \\
\text { bank employees involved in white-collar crime } \\
\text { because of the economic need to seek personal gain. }\end{array}$ & \\
\hline Exposure & Probability to be expressed & To become \\
\hline $\begin{array}{l}\text { Fraud and } \\
\text { white corral } \\
\text { crime can occur } \\
\text { if perceived } \\
\text { crime } \\
\text { disclosure is } \\
\text { low. }\end{array}$ & $\begin{array}{l}\text { Fraud or white corral crime Perpetrators, in general, } \\
\text { are resources that have higher education and } \\
\text { professional maturity so that they can guess the } \\
\text { potential for disclosure of fraud or criminal } \\
\text { behavior. The reality is that fraud or white-collar } \\
\text { crime is carried out by highly educated people who } \\
\text { have rights and established social and economic } \\
\text { status. }\end{array}$ & $\begin{array}{l}\text { an individual } \\
\text { who is an } \\
\text { opportunist. }\end{array}$ \\
\hline
\end{tabular}

The first discussions are consciousness and enlightenment stage. According to the Habermas language paradigm, social interactions between agents and principals in the agency theory basic framework are limited to the concept of system mechanism and included in the concept of life (Bukhori, 2012; Frankl, 2017). When viewed from the concept of system mechanism, the practice of fraud and white corral crime in banking services tends to be caused by economic media (money) and media power (principal pressure and rules). When viewed from the lifeworld concept, it is an effort to raise consciousness for bank employees not to commit fraud and white-collar crime with a basis for thinking beyond compliance. The idea of consciousness and enlightenment reflects the concepts of ethics, morality, and spirituality merged with GONE theory. The liberation effort will be carried out in this research. The use of Habermas theory in 
accounting research could reflect the role of humans as individual creatures as well as social beings as the basis for growing humanist values.

The second discussion is liberation from the materialistic person. This release aims to reduce the greed in a person who is the cause of fraud and white-collar crime. According to Sun et al. (2018), the main factor that shapes and influences a person to have a materialistic nature (work orientation only for material interests) is the feeling of interpersonal insecurity. This feeling occurs if someone feels anxious about his attachment to the environment in his circle and the social community. Then, he tends to attach himself to the material, not the person. Because of the material (money), according to him, he will not be able to leave it, unlike other people do.

When bank employees (agents) feel anxious and do not feel safe in their work, such as there is anxiety that the salary received is not enough to cost their needs and wants or when they feel depressed because they feel they cannot achieve the target imposed, then the interpersonal character will tend to be materially oriented. The proposed exemption effort is to provide and instill a sense of interpersonal security to all employees in financial security. This financial security is built based on ethical and moral values that the best work is work done in the best way and will result in the best remuneration. The perceived security of material needs will reduce greediness, which will impact efforts to eliminate the desire to cheat (Gonzalez \& Hoffman, 2018).

The third discussion is exemption from transactional materialism control and supervision. This exemption aims to reduce fraud and white corral crime opportunities through ethical and moral customer due diligence programs. The customer due diligence program is a step taken by banks in applying the principle of getting to know their customers well. The principle of ethical and moral customer due diligence will further indicate the bank's conservative attitude toward knowing their customers. This is not only done when someone opens a new account or becomes a new customer, but also when the person is already a bank customer.

The ethical and moral customer due diligence program for new customers is carried out by carefully matching customer information with supporting evidence, such as Identity Card, Driving Licence, and other supporting evidence if needed, filling out a complete deposit form, especially information on specific funding sources above 100 million rupiah. It must be evidenced by supporting documents that strengthen information on the source of funds. The bank must also ensure that the original customer's identity is not using a pseudonym to avoid misuse of accounts, one of which is related to money laundering. The bank will also conduct face-to-face validation to validate the truth of the customer's identity, which is not only done once, but can also be repeated by matching data in BI (BI checking). However, the customer due diligence program when they have become customers is carried out by looking at the transaction's historical compatibility with the customer's profile (Metekohy \& Nurhayati, 2012).

Researchers assess the crime of money laundering can also be said as an external threat to the bank. The best way for banks to protect themselves from these threats is to understand and get to know each customer as best as possible, along with what activities are carried out by the customer concerned in connection with account activities (customer due diligence). Besides, the principle of customer due diligence used as a concept and idea of release is how much the level of bank vigilance in assessing customers' ethical and moral profile. This is due to the white-collar crime committed by people with an economically respected social profile and social status but is weak in their ethical and moral profile. Thus, the higher the banks' vigilance in

This work is licensed under a Creative Commons Attribution-ShareAlike 4.0 International License. 
assessing the ethical and moral profile of their customers, the less chance of money laundering is. This method will be the primary protector for banks to prevent them from being used by criminals impersonating customers to launder money. Concerning this matter, Azam (2018) and Mira (2014) explains that customer due diligence is one of the main tools in preventing money laundering. Besides, customer due diligence is essential for applying prudential banking principles to protect banks from various risks in the relationship between customers and counter-party transactions.

The researcher also believes that imperfect customer due diligence principles can result in banks dealing with banking risks associated with assessing the public, customers, or partners of bank transactions. This is done concerning the bank concerned, namely, reputation risk, operational risk, legal risk, and concentration risk. Besides, the reputational risk relates to matters that can influence the public's assessment of the practices carried out by banks. This, eventually, can result in reduced public trust in bank integrity. In this case, banks are very vulnerable to reputation risk because they are the main target or the place for criminal activities that the customers can commit.

Operational risk is related to losses that directly or indirectly originate from internal or external banks. Legal risk relates to the possibility of banks being subjected to sanctions for not complying with customer due diligence standards. Banks may be subject to fines or sanctions by bank supervisory authorities or courts. Settlement of problems through the courts can have enormous cost implications for banks. Concentration risk is related to the assets and liabilities of the bank. In the practice of supervision, bank supervisors are concerned with information systems to identify the concentration of credit carried out by banks and the application of the precautionary principle by banks in channeling credit to creditors. Without knowing the customer's identity for specific and understanding the relationship between one customer and other customers, it is difficult for banks to overcome the risk of concentration concerned. However, on the liability side, concentration risk is related to the risk of funds, especially in the event of a sudden withdrawal in large numbers by customers, which results in bank liquidity.

The fourth discussion is the release of the rationale of selfish work relationships (individualist). This liberation aims to reduce the rationality of economic relations that tend to prioritize individual needs in all ways. The consciousness process becomes the release media by raising consciousness of bank employees who commit acts of fraud or white-collar crime or whoever is in the banking services business to avoid these two types of crime through the consciousness of their lives' meaningfulness. In that condition, a meaningfulness-life is a central theme of the existential personality theory of Victor Frankl (Earnshaw, 2004). Frankl (2017) believes that one's life's happiness is mainly supported by the passion for finding meaningfulness in life and the purpose of his existence.

As a bank employee, life's existence is happiness in providing bank services to their customers sincerely. This purpose is to be created so that there must be a strengthening of the spiritual value instilled in each bank employee's souls in his function as an agent according to agency theory (Bukhori, 2012). The reality is that agents behaving are not always encouraged and are encouraged to reduce tensions in the working relationship with the principal to gain balance and direct themselves towards specific goals that are appropriate for themselves, namely meaningfulness-life. Meaningfulness-life arises when a person feels spiritual maturation so that the purpose of his life will be devoted to happiness for worship (Fadhli \& Subandi, 2020; Fridayanti, 2013). 
When the quality of the agent's appreciation is on how much he can develop and actualize the potential and capacity, he will work and move to achieve his life's meaningfulness. This process can reduce the selfish and individualistic nature that has been inherent and vice versa. It can change into a person who is to realize the shared happiness. Consciousness of the meaningfulness of life that is no longer selfish is the individual agent's responsibility and cannot be entrusted to others because the agent himself feels and experiences the meaningfulness of his life.

Fifth discussing is that liberation becomes an opportunist. This exemption aims to reduce the perpetrators' possibility of using weaknesses in disclosing crime to commit fraud and white corral crime more and more broadly. Exemption is carried out through a process of logotherapy that seeks to provide consciousness about, e.g., First of all, the creative value or creativity, the agent in working relations with the principal must prioritize attitudes and ways of working that involve work dedication, sincerity, and truly love his work (Badua, 2019; Frankl, 2003). The agent in his duty is to provide service to customers and maintain good relations with those in the banking services business. Then, it produces the highest quality work while providing meaning. Secondly, it is the process of consciousness about the value of appreciation. The way to do this is to understand, appreciate, and believe that fraud and white corral crime have been open to opportunity. It is a crime that must be believed that it is a crime.

If the agent is aware of the value of the act, the next process is to make aware of and foster an attitude of not wanting to commit a crime even though the level of disclosure of legal and social sanctions is considered small. This argument is supported by Salama (2014), Mintchik, and Riley (2019), stating that the motive and psychological processes of people committing crime are the lack of consciousness and meaningfulness in their lives that greediness and opportunism are the beginning to commit corruption crimes.

The appreciation of the creative value, the appreciation value, and the attitude value incorporated in logotherapy can facilitate the compliance of bank employees (agents) with the banking regulation. This regulation is applied as part of the logotherapy process to apply the precautionary principle in sound banking practices. In this case, when the bank withdraws its customers to use the bank's services, it is expected that each transaction carried out by the customer through the bank is in line with sound banking practices, and it does not conflict with applicable regulations. Thus, since the beginning of the relationship between the bank and customers, the bank knows everything will be done by their customers and can prevent illegal transactions and involve both.

\section{CONCLUSION}

It can be inferred that the existence of an idea of consciousness and liberation is giving and instilling a sense of interpersonal security to all bank employees in the form of financial security. Besides, financial security is built based on ethical and moral values. The principle of ethical and moral customer due diligence will further demonstrate the bank's conservative attitude in getting to know their customers. This is done to reduce the relationship based on transactional materialism.

This study also makes us aware that an agent's life is primarily supported by the spirit to find meaningfulness in life and the purpose of his existence. As a bank employee, life's existence is happiness in providing bank services to their customers with sincerity, ethics, and morals. Finally, this study also offers liberation in the form of consciousness of the appreciation value for the agent and principal in its elaboration in

This work is licensed under a Creative Commons Attribution-ShareAlike 4.0 International License. 
agency theory. The way to do this is to understand, appreciate and believe that fraud and white corral crime that has been open to opportunity is a crime that must be believed as an act of crime, not as an opportunity used for the sake of money and ego.

This study's limitation is the limited time for interviews with informants so that awareness and release information that has grown in the environment of bank employees has not been revealed. The informant, who became a whistleblowing to express more complex motivation to commit fraud, was not fully open. Future research suggestions make the interview schedule with informants more flexible and sufficient time. Conduct a humanist approach with critical informants, especially whistleblowers, in order to obtain more open information.

\section{REFERENCES}

Azam, M. R. (2018). Theory Application: Why People Commit Fraud. International Journal of Management, Accounting \& Economics, 5(1), 54-65.

Badua, F. (2019). Lies, Sex, and Suicide: Teaching Fundamental Accounting Concepts with Sordid Tales from the Seamier Side of Accounting History. Accounting Historians Journal, 46(2), 53-59.

Baer, M. H. (2018). Sorting Out White-Collar Crime. Texas Law Review, 97(2), 225-283.

Berghoff, H., \& Spiekermann, U. (2018). Shady business: On the history of white-collar crime. Business History, 60(3), 289-304.

Bologna, J., Lindquist, R. J., \& Wells, J. T. (1993). The Accountant's Handbook of Fraud and Commercial Crime New York: Wiley.

Bukhori, B. (2012). Hubungan Kebermaknaan Hidup dan Dukungan Sosial Keluarga dengan Kesehatan Mental Narapidana. Jurnal Ad-Din, 4(1), 1-19.

C.Jensen, M., \& H.Meckling, W. (1976). Theory of the firm: Managerial behavior, agency costs, and ownership structure. Journal of Financial Economics, 3(4), 305360.

Donaldson, T., \& Preston, L. E. (1995). The stakeholder theory of the corporation: Concepts, evidence, and implications. Academy of Management Review, 20(1), 65-91.

Earnshaw, E. L. (2004). Religious Orientation and Meaning in Life: An Exploratory Study. MWSC Dept of Psychology Central Methodist College.

Fadhli, M., \& Subandi. (2020). Perubahan Makna Hidup Warga Binaan Tindak Pidana Korupsi di Lembaga Pemasyarakatan X. Psychopolytan: Jurnal Psikologi, 3(2), 112.

Frankl, V. E. (2003). Logoterapi: Terapi Psikologi Melalui Pemaknaan Eksistensi. Yogyakarta: Kreasi Wacana.

Frankl, V. E. (2017). Man's Search for Meaning. Jakarta: Noura.

Fridayanti. (2013). Pemaknaan hidup dalam kajian psikologi. Psikologika, 18(2), 1-12.

Garnasih, Y. (2013). Penanganan Kejahatan Aliran Dana Perbankan, Korupsi dan Pencucian Uang. Legalitas, IV(1), 22-34.

Gonzalez, G. C., \& Hoffman, V. B. (2018). Continuous Auditing's Effectiveness as a Fraud Deterrent. Auditing: A Journal of Practice \& Theory, 37(2), 225-247.

Hariyadi, D. (2019). Diduga Tilep Uang, Teller BRI Dijerat Pidana Pencucian Uang. Retrieved from bisnis.tempo.com

Hayashi, F. (2019). Payment Card Fraud Rates in The United States Relative to Other Countries After Migrating to Chip Cards. Economic Review, 104(4), 23-40.

Hikam, H. A. A. (2018). Bank Terbesar di Jerman Tersandung Kasus Pencucian Uang. Retrieved from finance.detik.com

Iwan. (2014). Menelaah Teori Kritis Jurgen Habermas. Jurnal Edueksos, 3(2), 145-165. 
J.R.Saroinsang, S. (2014). Konsep Strategis Perbanakan Dalam Pencegahan Tindak Pidana Pencucian Uang. Jurnal Edisi Khusus, II(2), 50-59.

Karyono. (2013). Forensic Fraud. Yogyakarta: Andi.

Ketz, J. E. (2019). Confessions of an Accounting Critic. CPA Journal, 89(3), 10-12.

Lai, T. K., Lei, A. C. H., \& Song, F. M. (2019). The Impact of Corporate Fraud on Director-Interlocked Firms: Evidence From Bank Loans. Journal of Business Finance \& Accounting, 46(2), 32-67.

Lan, L., \& Heracleos, L. (2010). Rethinking Agency Theory: The View From Law. Academy of Management Review, 35(2), 294-314.

Mathilda, F. (2013). Crime of Money Laundering in Banking Sector. Sigma-Mu 5(2), 5567.

Metekohy, E. Y., \& Nurhayati, I. (2012). Efektivitas Prinsip Mengenal Nasabah Pada Bank Sebagai Salah Satu Upaya Mencegah Tindak Pidana Pencucian Uang. Jurnal Ekonomi dan Bisnis, 11(1), 23-26.

Mintchik, N., \& Riley, J. (2019). Rationalizing Fraud. CPA Journal, 89(3), 44-50.

Mira, R. (2014). Upaya Pencegahan Pemberantasan Praktek Money Laudering oleh Perbankan Melalui Transfer Dana. Jurnal Edisi Khusus, 2(2), 60-69.

Omika dewi, I. G. A. A. (2010). Dialektika dan Refleksi Kritis Realitas "Sustainability" dalam Praktik Sustainability Reporting: Sebuah Narasi Habermasian. Jurnal Akuntansi dan Keuangan Indonesia, 7(2), 139-152.

Pluchart, J.-J. (2019). Le Triangle de La Fraude. Vie et Sciences de l'Entreprise, 1(207), 83-97.

Rechtman, Y. M. (2020). The Past, Present, and Future of Forensic Accounting. CPA Journal, 90(3), 10-12.

Reurink, A. (2018). Financial Fraud: a Literature Review. Journal of Economic Surveys, 32(5), 1292-1325.

Ruan, W., Xiang, E., \& Ma, S. (2018). Lending to Private Firms: Evidence from China on the Role of Firm Openness and Bribery. Chinese Economy, 51(1), 1-19.

Salama, N. (2014). Motif dan proses psikologis korupsi. Jurnal Psikologi, 41(2), 149-164.

Sawarjuwono, T. (2005). Bahasa Akuntansi Dalam Praktik: Sebuah Critical Accounting Study. TEMA (Telaah Ekonomi, Manajemen, dan Akuntansi), 6(2).

Shonhadji, N., \& Maulidi, A. (2020). Is it suitable for your local governments? A contingency theory-based analysis on the use of internal control in thwarting white-collarcrime Journal of Financial Crime, March (3)(1), 1-17.

Sridharan, U. V., \& Hadley, L. U. (2018). Internal Audit, Fraud and Risk Management at Wells Fargo. International Journal of The Academic Business World, 12(1), 4953.

Sun, Y., Wang, L., Jiang, J., \& Wang, R. (2018). Your love makes me feel more secure: Boosting attachment security decreases materialistic values. International Journal of Psychology, 2(1), 1-12.

Supraja, M. (2018). Pengantar Metodologi Ilmu Sosial Kritis Jurgen Habermas. Yogyakarta: Gajah Mada University Press.

Taylor, J. (2018). White-collar crime and the law in nineteenth-century Britain. Business History, 60(3), 343-360.

Weirich, T. R., \& Churyk, N. T. (2018). AIM Corporation: A Business Fraud Case Study. Journal of Forensic Accounting Research, 3(1), 37-51.

Yoon, K. S., \& Jun, J. (2019). Liability and Antifraud Investment In Fintech Retail Payment Services. Contemporary Economic Policy, 37(1), 181-194. 